\title{
Characterisation of Vibrio Species from Surface and Drinking Water Sources and Assessment of Biocontrol Potentials of Their Bacteriophages
}

\author{
Mpho Defney Maje, ${ }^{1}$ Christ Donald Kaptchouang Tchatchouang, ${ }^{1}$ \\ Madira Coutlyne Manganyi, ${ }^{2}$ Justine Fri $\mathbb{D}^{1},{ }^{1}$ and Collins Njie Ateba $\mathbb{D i}^{1}$ \\ ${ }^{1}$ Food Security and Safety Niche Area, Faculty of Natural and Agricultural Sciences, North-West University, Mmabatho, \\ Mafikeng 2735, South Africa \\ ${ }^{2}$ Department of Microbiology, School of Biological Sciences, Faculty of Natural and Agricultural Sciences, North-West University, \\ Private Bag X2046, Mmabatho, South Africa
}

Correspondence should be addressed to Collins Njie Ateba; collins.ateba@nwu.ac.za

Received 24 May 2020; Revised 7 July 2020; Accepted 17 July 2020; Published 4 August 2020

Academic Editor: Giuseppe Comi

Copyright (C 2020 Mpho Defney Maje et al. This is an open access article distributed under the Creative Commons Attribution License, which permits unrestricted use, distribution, and reproduction in any medium, provided the original work is properly cited.

\begin{abstract}
The aim of this study was to characterise Vibrio species of water samples collected from taps, boreholes, and dams in the North West province, South Africa, and assess biocontrol potentials of their bacteriophages. Fifty-seven putative Vibrio isolates were obtained on thiosulfate-citrate-bile-salt-sucrose agar and identified using biochemical tests and species-specific PCRs. Isolates were further characterised based on the presence of virulence factors, susceptibility to eleven antibiotics, and biofilm formation potentials. Twentytwo (38.60\%) isolates were confirmed as Vibrio species, comprising V. harveyi (45.5\%, $n=10)$, V. parahaemolyticus $(22.7 \%, n=5)$, $V$. cholerae $(13.6 \%, n=3)$, V. mimicus $(9.1 \%, n=2)$, and V. vulnificus $(9.1 \%, n=2)$. Three of the six virulent genes screened were positively amplified; four $V$. parahaemolyticus possessed the $t d h(18.18 \%)$ and $\operatorname{trh}(18.18 \%)$ genes, while the zot gene was harboured by $3 \mathrm{~V}$. cholerae (13.64\%) and one V. mimicus (4.55\%) isolate. Isolates revealed high levels of resistance to cephalothin (95.45\%), ampicillin (77.27\%), and streptomycin (40.91\%), while lower resistances (4.55\%-27.27\%) were recorded for other antimicrobials. Sixteen $(72.7 \%)$ isolates displayed multiple antibiotic-resistant properties. Cluster analysis of antibiotic resistance revealed a closer relationship between Vibrio isolates from different sampling sites. The Vibrio species displayed biofilm formation potentials at $37^{\circ} \mathrm{C}$ $(63.6, n=14), 35^{\circ} \mathrm{C}(50 \%, n=11)$, and $25^{\circ} \mathrm{C}(36.4 \%, n=8)$. Two phages isolated in this study (vB_VpM_SA3V and vB_VcM_SA3V) were classified as belonging to the family Myoviridae based on electron microscopy. These were able to lyse multidrug-resistant $V$. parahaemolyticus and $V$. cholerae strains. These findings not only indicate the presence of antibiotic-resistant virulent Vibrio species from dam, borehole, and tap water samples that could pose a health risk to humans who either come in contact with or consume water but also present these lytic phages as alternative agents that can be exploited for biological control of these pathogenic strains.
\end{abstract}

\section{Introduction}

Infections caused by pathogenic Vibrios remain a severe threat to the public. Most of these infections result from the consumption of undercooked seafood products or contaminated water [1]. Also, person-to-person transmission has been documented [2]. These infections are classified into cholera and noncholera types [3]. Vibrio cholerae infections can be fatal if not properly managed $[4,5]$.
Noncholera infections range from self-limiting gastroenteritis to severe life-threatening septicaemia and necrotizing fasciitis [1]. V. cholerae and V. parahaemolyticus are mostly associated with human infections [6, 7]. However, other Vibrios, such as $V$. alginolyticus, $V$. harveyi, $V$. anguillarum, V. mimicus, V. metschnikovii, V. vulnificus, and $V$. fluvialis, which have been detected, particularly in marine environments, are now considered as emerging human pathogens [8]. 
A variety of virulence factors are exhibited by pathogenic Vibrios responsible for cholera and noncholera infections. Generally, the ability of Vibrio cholerae to cause disease largely depends on the production of the toxin-coregulated pilus (TCP) and the cholera toxin (CT). The integrated prophage CTX $\phi$-located $c t x B$ and $c t x A$ genes encode the CT, which is implicated in diarrhoea with dehydration and electrolyte loss [9]. In contrast, TCP coded by $\operatorname{tcp} A$ aids the pathogen to colonise the epithelium of the small intestine. The ToxR regulon regulates the expression of these genes in response to external stimuli [9]. The major contributors to $V$. parahaemolyticus pathogenicity are the thermostable direct haemolysin $(t r h)$ and the thermostable direct haemolysin-related (trh) genes [10-12]. The biological impacts of these proteins include hemolytic as well as cytotoxic effects [13]. The virulence of $V$. vulnificus is encoded by the $v c g$ gene. The degree of virulence in this species is related to its origin whereby higher virulence is demonstrated by clinical isolates than environmental strains. Conversely, Vibrio fluvialis has been shown to produce numerous potent toxins. Just as in $V$. cholerae, the ToxR gene is an important virulence determinant of $V$. fluvialis. Others include the heat stable enterotoxin, hupO, vfp, and $v f h$ genes [14, 15].

Antibiotics and other antimicrobial agents have been used, since their discovery, for the treatment and management of bacterial infections in humans and animals [16]. The treatment of Vibrio infections in humans includes the use of doxycycline as the preferred drug for the elderly, while azithromycin is recommended for pregnant women and children [1]. Unfortunately, there is an ever-increasing resistance displayed by several bacterial strains against commonly used and recommended antimicrobial agents. Antibiotic resistance, therefore, is a severe challenge to therapy and can account for a large proportion of therapeutic failures, resulting in high morbidity and mortality $[17,18]$. Consequently, immediate solutions are needed to limit the spread of resistant bacteria/determinants.

The biofilm-producing ability of bacterial species further complicates antibiotic resistance. Such strains are enclosed in an exopolysaccharide matrix component adhered to a solid surface, which provides both structural and protective functions to bacterial strains. The ability to form biofilms is, therefore, a fundamental component to ensure environmental survival and transmission [19, 20]. Properties expressed by biofilm-forming cells are distinct from those of planktonic cells. One of such properties is increased resistance to antimicrobial agents compared to planktonic cells [19]. Bacteria biofilms, even when present at very low detection limits in water, act as a constant environmental reservoir for continual water contamination [21].

With the increase in antibiotic-resistant human pathogenic infections, there is a renewed interest in the search for novel and alternative therapeutic or biocontrol agents against clinically relevant bacteria. Bacteriophages are regarded as promising bacterial agents, highlighting their importance as novel therapeutic agents [22, 23]. Some studies have revealed that the combination of different phage stocks in a single experiment improves the host range. Such combination also enhances virulence capabilities against resistant strains compared to individual phages $[24,25]$.
Consumption of contaminated water is one of the sources of Vibrio infections. South Africa is located in a semiarid region and receives very less rainfall, resulting in shortage of potable water. Most individuals, therefore, resort to water from unprotected sources, such as rivers, boreholes, and dams, for daily activities, such as irrigation, cooking, and even drinking [26]. Unfortunately, microbial contamination of such unprotected water bodies is a significant cause of a large proportion of water-associated epidemics [27-29]. The significant number of reports confirming the presence of pathogenic microorganisms in water consumed by people in rural communities in the North West province of South Africa also informed the need to conduct the study [30-34]. Thus, in this study, virulent Vibrio species of water samples collected from taps, boreholes, and dams in the North West Province, South Africa, were characterised, and the lytic potentials of Vibrio-specific bacteriophages were assessed for potential exploitation of biocontrol agents against pathogenic Vibrio strains.

\section{Materials and Methods}

2.1. Ethical Clearance. This study was approved by the Research Ethics Committee of the North-West University, South Africa (ethical clearance number: NWU-00725-18A9).

2.2. Collection of Samples. One hundred and thirty-six (136) water samples were collected from taps, boreholes, and dams from 20 randomly selected areas and communities in the North West province, South Africa (Figure 1) using sterile $500 \mathrm{~mL}$ Duran Schott bottles. For borehole and tap water samples, taps were allowed to run for about five minutes to purge water from the pipes and draw fresh water from the water supply system. The lid from the sample container was removed, and without touching the inside of the bottle or lid, the container was filled with $100 \mathrm{~mL}$ of water. For dam water samples, the lid from the sample container was also removed, and without touching the inside of the bottle or lid, the container was immediately filled with $100 \mathrm{~mL}$ of water. The lid was tightly closed to prevent leakage. The samples were properly labelled and transported on ice to the laboratory for analysis. The number of water samples collected from different areas is presented in Supplementary Table 1. These sites were selected because previous studies in the North West province have revealed the presence of virulent and multidrug-resistant strains in either food or water samples [30-34]. The choice of these sites not only reflects the desire to contribute towards finding potential solutions regarding the worrying trends associated with challenges of treating infections resulting from the spread of resistant bacterial strains within communities but also in addressing problems that are common in our immediate local environment.

2.3. Sample Processing and Isolation of Vibrio Species. Water samples were analysed immediately upon arrival in the laboratory. For each water sample, $100 \mathrm{~mL}$ was filtered 


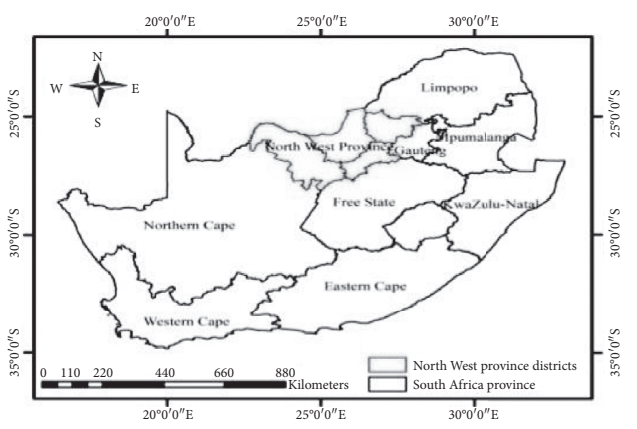

(a)

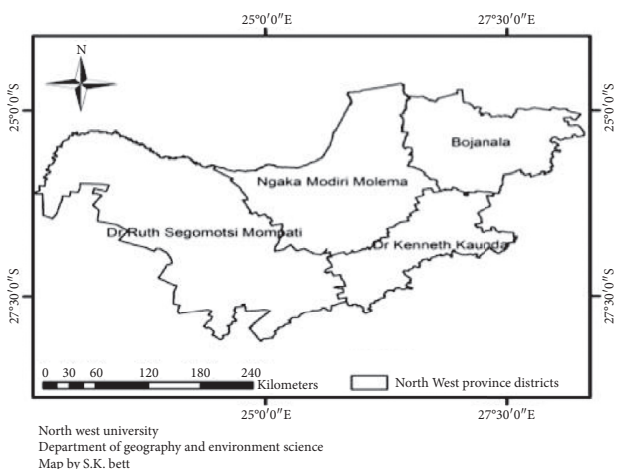

(b)

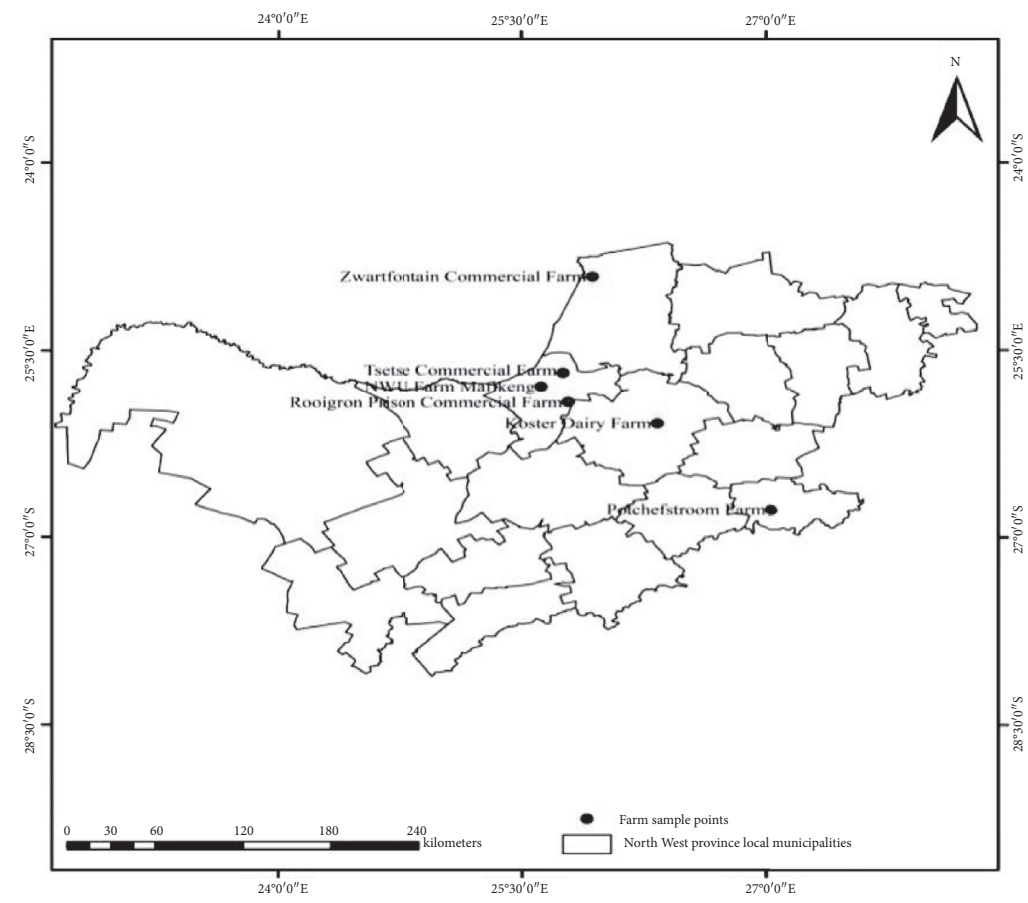

(c)

FIGURE 1: Sampling sites.

through $0.45 \mu \mathrm{m}$ membrane filters (Sigma-Aldrich, Missouri, USA), and the filter papers were inoculated on thiosulfate-citrate-bile-salt-sucrose (TCBS) agar (Merck, Darmstadt, Germany) [35]. Plates were incubated aerobically at $37^{\circ} \mathrm{C}$ for 24 hours. After incubation, colonies with different morphotypes were subcultured on TCBS, and plates were incubated aerobically at $37^{\circ} \mathrm{C}$ for 24 hours. Pure isolates were stored at $4^{\circ} \mathrm{C}$ for further analysis. Preliminary identification of isolates was done using Gram staining, biochemical tests (oxidase test, triple sugar iron agar, and Simmons citrate agar), salt tolerance, and motility tests. Presumptive isolates were stored in $20 \%$ (v/v) glycerol at $-80^{\circ} \mathrm{C}$ for future analysis.

2.4. Molecular Characterisation of Vibrio Species. Genomic DNA was isolated from all presumptive Vibrio isolates using the cetyltrimethylammonium bromide (CTAB) method with slight modifications [36]. The quality and purity of the DNA were determined using a spectrophotometer (version UV-visible spectrophotometer model S-22, Boeco, Germany) at wavelengths of $260 \mathrm{~nm}$ and $280 \mathrm{~nm}$. Molecular identification of isolates was performed using polymerase chain reaction (PCR) assay. Fragments of the bacterial 16S rRNA gene were amplified as an internal control for all presumptive isolates, using universal oligonucleotide primers $27 \mathrm{~F}$ and 1492R [37], while speciesspecific primers were used to identify species. Target genes included $\operatorname{sodB}(1)$ and $o m p W$ for $V$. cholerae, $r f b$ specific for $V$. cholerae serogroup $\mathrm{O} 1$, the flaE gene for $V$. parahaemolyticus, hsp for V. vulnificus, sodB for V. mimicus, and wh for $V$. harveyi (Table 1).

2.5. Detection of Vibrio Virulence Genes. Virulence gene determinants in Vibrio species were determined by PCR amplification of the $t d h, t r h, c t x A B, z o t, f l r A$, and $v p s R$ gene sequences. These genes, which were thought to only be 
TABLE 1: Oligonucleotide primers used for PCR amplification of Vibrio species-specific gene fragments.

\begin{tabular}{|c|c|c|c|c|c|}
\hline Target organism & Primer sequence $\left(5^{\prime}-3^{\prime}\right)$ & $\begin{array}{c}\text { Targeted } \\
\text { gene }\end{array}$ & $\begin{array}{l}\text { Amplicon } \\
\text { size (bp) }\end{array}$ & PCR cycling conditions & Reference \\
\hline $\begin{array}{l}\text { All bacterial strains } \\
\text { (universal } 16 \mathrm{~S} \\
\text { rRNA gene sequence) }\end{array}$ & $\begin{array}{l}\text { 27F: AGAGTTTGATCATGGCTCAG } \\
\text { 1492R: GGTACCTTGTTACGACTT }\end{array}$ & $\begin{array}{l}16 S \\
\text { rRNA }\end{array}$ & 1420 & $\begin{array}{l}\text { Initial denaturation at } 94^{\circ} \mathrm{C} \text { for } \\
3 \text { minutes, } 25 \text { cycles of denaturation } \\
\text { at } 94^{\circ} \mathrm{C} \text { for } 1 \text { minute, primer annealing } \\
\text { at } 55^{\circ} \mathrm{C} \text { for } 1 \text { minute, elongation } \\
\text { at } 72^{\circ} \mathrm{C} \text { for } 2 \text { minutes, and a final strand } \\
\text { elongation step at } 72^{\circ} \mathrm{C} \text { for } 10 \text { minutes. }\end{array}$ & {$[37]$} \\
\hline $\begin{array}{l}V . \text { cholerae } \\
\text { serogroup } \mathrm{O} 1\end{array}$ & $\begin{array}{l}\text { F: CACCAAGAAGGTGACTTTATT } \\
\text { GTG } \\
\text { R: GGTTTGTCGAATTAGCTTCACC }\end{array}$ & ompW & 638 & $\begin{array}{l}\text { Initial denaturation at } 94^{\circ} \mathrm{C} \text { for } \\
10 \text { minutes, } 30 \text { cycles of denaturation } \\
\text { at } 94^{\circ} \mathrm{C} \text { for } 1 \text { minute, primer annealing } \\
\text { at } 59^{\circ} \mathrm{C} \text { for } 1 \text { minute, elongation } \\
\text { at } 72^{\circ} \mathrm{C} \text { for } 2 \text { minutes, and a final } \\
\text { strand elongation at } 72^{\circ} \mathrm{C} \text { for } 10 \text { minutes. }\end{array}$ & {$[38]$} \\
\hline V. cholerae & $\begin{array}{c}\text { F: AAGACCTCAACTGGCGGTA } \\
\text { R: } \\
\text { GAAGTGTTAGTGATCGCCAGAGT }\end{array}$ & $\operatorname{sod} B(1)$ & 248 & \multirow{4}{*}{$\begin{array}{l}\text { Initial denaturation at } 95^{\circ} \mathrm{C} \text { for } \\
10 \text { minutes, } 35 \text { cycles of denaturation } \\
\text { at } 92^{\circ} \mathrm{C} \text { for } 40 \text { seconds, primer annealing } \\
\text { at } 57^{\circ} \mathrm{C} \text { for } 1 \text { minute, elongation at } \\
72^{\circ} \mathrm{C} \text { for } 1.5 \text { minutes, and a final strand } \\
\text { elongation at } 72^{\circ} \mathrm{C} \text { for } 10 \text { minutes. }\end{array}$} & \multirow{4}{*}{ [39] } \\
\hline$V \cdot$ parahaemolyticus & $\begin{array}{l}\text { F: GCAGCTGATCAAAACGTTGAGT } \\
\text { R: ATTATCGATCGTGCCACTCAC } \\
\text { F: GTCTTAAAGCGGTTGCTGC }\end{array}$ & flaE & 897 & & \\
\hline V. vulnificus & $\begin{array}{l}\text { R: CGCTTCAAGTGCTGGTAGAAG } \\
\text { F: CATTCGGTTCTTTCGCTGAT }\end{array}$ & hsp60 & 410 & & \\
\hline V. mimicus & $\begin{array}{c}\text { R:GAAGTGTTAGTGATTGCTAG } \\
\text { AGAT } \\
\end{array}$ & $\operatorname{sod} B$ & 121 & & \\
\hline V. harveyi & $\begin{array}{l}\text { F: CTTCACGCTTGATGGCTACTG } \\
\text { R: GTCACCCAATGCTACGACCT }\end{array}$ & vhh & 235 & $\begin{array}{l}\text { Initial denaturation at } 95^{\circ} \mathrm{C} \text { for } \\
10 \text { minutes, } 30 \text { cycles of } \\
\text { denaturation at } 95^{\circ} \mathrm{C} \text { for } 1 \text { minute, } \\
\text { primer annealing at } 50^{\circ} \mathrm{C} \text { for } 1 \text { minute, } \\
\text { elongation at } 72^{\circ} \mathrm{C} \text { for } 1 \text { minute, and a final } \\
\text { strand elongation at } 72^{\circ} \mathrm{C} \text { for } 10 \text { minutes. }\end{array}$ & {$[40]$} \\
\hline
\end{tabular}

specific to either $V$. parahaemolyticus ( $t d h$ and $t r h$ ) or $V$. cholerae (ctxAB, zot, flrA, and $v p s R$ ), have been detected from other environmental Vibrios [8]. The oligonucleotide sequences, target genes, amplicon sizes, and cycling conditions of the PCR assays are listed in Table 2. All PCR reactions were prepared in a standard $25 \mu \mathrm{L}$ volume, comprising $12.5 \mu \mathrm{L}$ of $2 \mathrm{X}$ DreamTaq Green Master Mix (0.4 mM dATP, $0.4 \mathrm{mM}$ dCTP, $0.4 \mathrm{mM}$ dGTP, and $0.4 \mathrm{mM}$ dTTP, $4 \mathrm{mM} \mathrm{MgCl}_{2}$, and loading buffer) (Fermentas, USA), $11 \mu \mathrm{L}$ nuclease-free water (Fermentas, USA), $0.25 \mu \mathrm{L}$ of each forward and reverse primers (Inqaba Biotechnologies, Pretoria), and $1 \mu \mathrm{L}$ of template DNA. Amplifications were performed in a C1000 Touch ${ }^{\mathrm{TM}}$ Thermal Cycler (Bio-Rad, UK). Amplicons were resolved by electrophoresis on a $2 \%$ $(\mathrm{w} / \mathrm{v})$ agarose gel at $90 \mathrm{~V}$ for 50 minutes and visualised using a ChemiDoc ${ }^{\mathrm{TM}}$ MP Imaging System (Bio-Rad, UK).

2.6. Antimicrobial Susceptibility Test. The Kirby-Bauer disc diffusion assay was used to determine the antimicrobial resistance patterns of confirmed Vibrio isolates in accordance with the guidelines of the Clinical Laboratory Standards Institute $[42,43]$. Vibrio isolates were screened against a panel of eleven antimicrobial agents (Mast Diagnostics, UK) belonging to seven classes. A bacterial suspension of each pure isolate was prepared in $0.8 \%(\mathrm{w} / \mathrm{v})$ sterile physiological saline, vortexed, and the optical density adjusted to the $0.5 \mathrm{McF}$ arland standards. Aliquots of $100 \mu \mathrm{L}$ inoculum from each suspension were spread-plated onto Mueller-Hinton agar plates. Antimicrobial-impregnated discs were placed at equal distances on the inoculated plates. The antimicrobial agents included the following: ampicillin (AMP), $10 \mu \mathrm{g}$; cephalothin (CEF), $30 \mu \mathrm{g}$; chloramphenicol (CHL), $30 \mu \mathrm{g}$; ciprofloxacin (CIP), $5 \mu \mathrm{g}$; tetracycline (TET), $30 \mu \mathrm{g}$; gentamicin (GEN), $10 \mu \mathrm{g}$; kanamycin (KAN), $30 \mu \mathrm{g}$; nalidixic acid (NAL), $30 \mu \mathrm{g}$; trimethoprim-sulfamethoxazole (TS), $1.25 / 23.75 \mu \mathrm{g}$; streptomycin (STR), $10 \mu \mathrm{g}$; and trimethoprim (TMP), $5 \mu \mathrm{g}$. The plates were incubated at $37^{\circ} \mathrm{C}$ for 24 hours, and the inhibition zone diameters were measured. Values obtained were interpreted in accordance with the CLSI interpretive criteria [43].

2.7. Biofilm Formation Assay. Biofilm formation assay was performed in a 96-well microtiter plate according to the method described earlier [44]. In brief, bacteria were grown in nutrient broth $(\mathrm{NB})$ at $37^{\circ} \mathrm{C}$ for 24 hours. Two hundred microlitres of $1: 100$ overnight cultures in fresh NB were dispensed into wells and incubated at $37^{\circ} \mathrm{C}$ for 24 hours. Negative control wells consisted of uninoculated sterile NB. The contents of wells were discarded and washed twice with phosphate buffer saline (PBS). Two hundred microlitres of $1 \%(\mathrm{w} / \mathrm{v})$ crystal violet dye were added to each well followed by incubation of plates at room temperature for 1 hour. The dye was discarded, and the wells were washed five times with PBS and allowed to dry at room temperature. Two hundred microlitres of $95 \%(\mathrm{v} / \mathrm{v})$ ethanol were added to the wells, with further incubation at room temperature for 5 minutes. Ethanol was transferred to wells of new microtiter plates, and the optical density at $630 \mathrm{~nm}$ was recorded. The protocol was repeated with initial bacterial incubation of the plates at $35^{\circ} \mathrm{C}$ and $25^{\circ} \mathrm{C}$. The biofilm-producing potential of isolates 
TABLE 2: Primer sequences and PCR amplification conditions for the detection of Vibrio virulent genes.

\begin{tabular}{|c|c|c|c|c|}
\hline Target gene & Primer sequence $\left(5^{\prime}-3^{\prime}\right)$ & $\begin{array}{l}\text { Amplicon } \\
\text { size (bp) }\end{array}$ & PCR cycling conditions & Reference \\
\hline$t d h$ & $\begin{array}{l}\text { F: GTAAAGGTCTCTGACTTTTGGAC } \\
\text { R: TGGAATAGAACCTTCATCTTCACC }\end{array}$ & 270 & \multirow{2}{*}{$\begin{array}{l}\text { Initial denaturation at } 94^{\circ} \mathrm{C} \text { for } 3 \text { minutes, } \\
30 \text { cycles of denaturation at } 94^{\circ} \mathrm{C} \text { for } 1 \text { minute, } \\
\text { primer annealing at } 58^{\circ} \mathrm{C} \text { for } 1 \text { minute, } \\
\text { elongation at } 72^{\circ} \mathrm{C} \text { for } 1 \text { minute, and a } \\
\text { final strand elongation at } 72^{\circ} \mathrm{C} \text { for } 5 \text { minutes. }\end{array}$} & \multirow[b]{2}{*}[10]{} \\
\hline trh & $\begin{array}{l}\text { F: TTGGCTTCGATATTTTCAGTATCT } \\
\text { R: CATAACAAACATATGCCCATTTCCG }\end{array}$ & 486 & & \\
\hline $\operatorname{ctx} A B$ & $\begin{array}{l}\text { F: GCCGGGTTGTGGGAATGCTCCAAG } \\
\text { R: GCCATACTAATTGCGGCAATCGCATG }\end{array}$ & 536 & \multirow{2}{*}{$\begin{array}{l}\text { Initial denaturation at } 94^{\circ} \mathrm{C} \text { for } 10 \text { minutes, } \\
30 \text { cycles of denaturation at } 94^{\circ} \mathrm{C} \text { for } 1 \text { minute, } \\
\text { primer annealing at } 59^{\circ} \mathrm{C} \text { for } 1 \text { minute, } \\
\text { elongation at } 72^{\circ} \mathrm{C} \text { for } 2 \text { minutes, and a } \\
\text { final strand elongation at } 72^{\circ} \mathrm{C} \text { for } \\
10 \text { minutes. }\end{array}$} & \multirow[b]{2}{*}[41]{} \\
\hline$z o t$ & $\begin{array}{l}\text { F: TCGCTTAACGATGGCGCGTTTT } \\
\text { R: AACCCCGTTTCACTTCTACCCA }\end{array}$ & 947 & & \\
\hline$f l r A$ & $\begin{array}{l}\text { F: GAGGCAACAGCACCATCAAA } \\
\text { R: CGCATCTATATCAGGGACAA }\end{array}$ & 503 & \multirow{2}{*}{$\begin{array}{l}\text { Initial denaturation at } 95^{\circ} \mathrm{C} \text { for } 5 \text { minutes, } \\
35 \text { cycles of denaturation at } 95^{\circ} \mathrm{C} \\
\text { for } 45 \text { seconds, primer annealing } \\
\text { at } 72^{\circ} \mathrm{C} \text { for } 45 \text { seconds, and a final strand } \\
\text { elongation at } 72^{\circ} \mathrm{C} \text { for } 15 \text { minutes. }\end{array}$} & \multirow[b]{2}{*}[8]{} \\
\hline$v p s R$ & $\begin{array}{l}\text { F: GGTGAGTAGCCATAAGCAAG } \\
\text { R: CATCCAGCACCACAGTATCT }\end{array}$ & 911 & & \\
\hline
\end{tabular}

was classified as follows: biofilm formation if $\mathrm{OD}_{\text {test }}<\mathrm{OD}_{\text {control; }}$ weak biofilm formation if $\mathrm{OD}_{\text {control }}<\mathrm{OD}_{\text {test }}<2 \mathrm{OD}_{\text {control }}$; moderate biofilm formation if $2 \mathrm{OD}_{\text {control }}<\mathrm{OD}_{\text {test }}<4 \mathrm{OD}_{\text {control }}$; and strong biofilm formation if $4 \mathrm{OD}_{\text {control }}<\mathrm{OD}_{\text {test. }}$

\subsection{Bacteriophage Assay}

2.8.1. Isolation of Vibrio Phages. Isolation of phages was done using the double agar layer method [45]. Five of the PCR-confirmed Vibrio isolates were used to isolate bacteriophages from sewage water. Ten millilitres of water were suspended in $10 \mathrm{~mL}$ of lambda diluent $(10 \mathrm{mM}$ Tris $\mathrm{HCl}(\mathrm{pH}$ 7.5 ) and $8 \mathrm{mM} \mathrm{MgSO} 4.7 \mathrm{H}_{2} \mathrm{O}$ ), vortexed thoroughly, and incubated at room temperature for 60 minutes. This was followed by centrifugation of the samples at $5,250 \times \mathrm{g}$ for 10 minutes to sediment the bacterial cells. Each supernatant was extracted and further centrifuged followed by filtering through a $0.22 \mu \mathrm{m}$ pore syringe filter (GVS Filter Technology, USA). Crude filtrates were enriched in Tryptic Soy Broth (TSB) and incubated at $37^{\circ} \mathrm{C}$ for 60 minutes.

Phage activity was determined using the following procedures: ten-fold serial dilutions of the phage lysates were prepared using lambda diluent; aliquots $(100 \mu \mathrm{L})$ of each dilution were added to $100 \mu \mathrm{L}$ of log phase Vibrio species host bacteria cultured in TSB containing $10 \mathrm{Mmol} / \mathrm{L} \mathrm{MgSO}_{4}$; the mixture was incubated at room temperature for 10 minutes to facilitate attachment; an aliquot of $3 \mathrm{~mL}$ of $0.6 \%$ $(\mathrm{w} / \mathrm{v})$ agarose, cooled to about $50^{\circ} \mathrm{C}$, was added into each mixture, and the contents were poured on solidified modified nutrient agar (MNA); and plates were incubated aerobically at $37^{\circ} \mathrm{C}$ for 24 hours followed by observation of the plaques.

2.8.2. Purification, Enumeration, and Propagation of Phages. Plaques were picked from plates using sterile pipette tips and inoculated in $1.5 \mathrm{~mL}$ of Difco phage broth (DPB) and incubated overnight at $4^{\circ} \mathrm{C}$ for phages to diffuse out of agarose. Phages in the lysates were purified three times in succession by single-plaque isolation, and in each case, stock filtrates were prepared using suitable host strains as described previously [46]. Titers of isolated phages in stock filtrates were also determined using the soft layer overlay technique [47]. The purified bacteriophage lysates were stored at $4^{\circ} \mathrm{C}$.

Phage propagation was carried out by centrifuging phages in DFB at $10,000 \times \mathrm{g}$ for 2 minutes, and an equal volume $(1 \mathrm{~mL})$ of the resulting lysate and overnight broth culture of each Vibrio strain were added to $5 \mathrm{~mL}$ of DPB. The mixture was incubated at $37^{\circ} \mathrm{C}$ in a shaking water bath for 67 hours. The phage lysates were centrifuged at 9,000 $\times \mathrm{g}$ for 15 minutes to remove bacterial debris, and the supernatant was filtered through a $0.2 \mu \mathrm{m}$ pore-size Super Acrodisc syringe filter.

\subsection{Characterisation of Bacteriophages}

2.9.1. Electron Microscopy. Phages were purified using polyethylene glycol (PEG), in accordance with standard procedures [48]. Phage suspensions were centrifuged at $25,000 \times \mathrm{g}$ for 60 minutes, and the resulting pellets were washed twice in ammonium acetate $\left(0.1 \mathrm{moll}^{-1}, \mathrm{pH} 7.0\right)$. Pellets were subjected to transmission electron microscopy. Each phage was assigned a name as previously described [49], comprising vB (bacterial virus) followed by $\mathrm{Vp}$ and ( $V$. parahaemolyticus) or Vc (V. cholerae), M (Myoviridae), SA (South Africa), numbers (sample identity) followed by K or $\mathrm{V}$, etc., (sampling site). For example, a phage isolated from Ventersdorp using V. parahaemolyticus, as the host strain, was designated vB_VpM_SA3V.

2.9.2. Microplate Phage Virulence Assay and Host Specificity. The lytic capabilities of the phages were assessed using the microplate phage virulence assay as earlier described [46] 
with slight modifications. Aliquots of $180 \mu \mathrm{L}$ of each of the 22 overnight bacteria cultures were mixed with $20 \mu \mathrm{L}$ of filtered phage lysates in a 96-well microtiter plate and incubated at $37^{\circ} \mathrm{C}$ for 5 hours. TSB was used as a blank, while the overnight cultures were used as negative controls. Treatments were carried out in triplicates. Wells were examined visually for turbidity due to bacterial growth. Also, a spectrophotometer was used to read the results and compare the OD readings with results from the visual analysis of the plates. Results were interpreted as positive when there was inhibition of bacterial growth or negative when bacterial growth was not inhibited.

2.9.3. Stability of Varying Temperatures and $p H$ of Phages. The stability of the phages at different $\mathrm{pH}$ and temperatures was assessed as previously described, with slight modifications [46]. For the stability of phages to various $\mathrm{pH}, 100 \mu \mathrm{l}$ of phage lysates was added to $900 \mu \mathrm{l}$ of $\mathrm{pH}$-adjusted TSB $(0,4.2$, $6.3,7,8$, and 10). The tubes were incubated at room temperature for 5 hours followed by the determination of phage titer using the soft agar overlay technique. The stability of phages to different temperatures was determined by incubating phage lysates of known concentrations at $37^{\circ} \mathrm{C}, 45^{\circ} \mathrm{C}$, $55^{\circ} \mathrm{C}$, and $60^{\circ} \mathrm{C}$ for 1 hour followed by the determination of phage titers using the soft agar overlay method.

2.10. Statistical Analysis. Bacteria growth inhibition zone diameter data of isolates from different stations were used to perform a cluster analysis, using the Wards algorithm and Euclidean distances on Statistica software, version 12 (Statsoft, US). The analysis was done to determine the relatedness of isolates based on the history of antibiotic exposure.

\section{Results}

3.1. Occurrence of Vibrio in Water Samples. Fifty-seven nonrepetitive presumptive Vibrio isolates that presented different macroscopic colonial morphologies were obtained through the culture. Out of this number, 20 were from tap water, 32 from boreholes, and 5 from dam water. All the isolates were Gram-negative rod-shaped bacteria that fermented the sugars in the TSI medium and did not result in blackening of the medium, thus unable to produce hydrogen sulphide gas. The isolates were unable to utilise sodium citrate as the sole source of carbon. All the isolates grew at $0 \%, 3 \%, 6 \%$, and $10 \%(\mathrm{w} / \mathrm{v}) \mathrm{NaCl}$ solution, with the exception of one isolate that did not tolerate $6 \%$ and $10 \%$ salt.

Fragments of the bacterial 16S rRNA gene were amplified in all the 57 presumptive isolates and further subjected to Vibrio species-specific PCR identification assays. Twenty-two presumptive isolates were identified: a large proportion $(45.45 \% n=10)$ was detected as $V$. harveyi followed by $V$. parahaemolyticus $5(22.73 \%)$ and $V$. cholerae 3 (13.64\%), and the least were $V$. mimicus and $V$. vulnificus, with two (9.1\%) isolates each. These constituted 7, 4, and 11 isolates from taps, dams, and boreholes, respectively. A detailed summary of the number of species detected in different samples is given in Table 3, while Figures 2 and 3 are representative gels, showing fragments of different genes amplified for identification of Vibrio species.

3.2. Prevalence of Virulent Genes. Three of the six virulent genes screened were detected. Four out of five $V$. parahaemolyticus isolates (80\%) constituting $18.2 \%$ of the total Vibrios detected in this study harboured the $t d h$ virulent gene. This comprised all three isolates from Lonely Park and one from Ramosadi. Similarly, four V. parahaemolyticus, comprising two each from borehole water in Ramosadi and Lonely Park, were positive for trh. A similar number, four $(18.18 \%)$ isolates possessed the zot virulent gene, three $V$. cholerae from Pella and one (1) V. mimicus from Seweding. Figure 4 is a $2 \%(\mathrm{w} / \mathrm{v})$ image of agarose gel obtained from different virulent genes amplified during the study.

3.3. Antibiotic Susceptibility Profiles of Isolates. Out of the twenty-two isolates assayed, the highest percentages of resistance were observed for cephalothin $(95.5 \%, n=21)$ followed by ampicillin $(77.3 \%, n=17)$, streptomycin $(40.9 \%$, $n=9)$, nalidixic acid $(27.3 \%, n=6)$, and tetracycline $(22.7 \%$, $n=5)$. However, $3(13.6 \%)$ isolates were resistant to gentamycin, kanamycin, and trimethoprim, 2 (9.1\%) to chloramphenicol, and 1 (4.5\%) to trimethoprimsulfamethoxazole and ciprofloxacin. All isolates displayed resistance properties to at least one antimicrobial tested. Multiple-antibiotic resistance (resistance to 3 or more antibiotic classes) was recorded in $16(72.7 \%)$ isolates with $A P^{R}-C F^{R}-T^{R}-S^{R}$ representing the dominant phenotype observed in $4(18.2 \%)$ isolates. Table 4 shows the proportion of Vibrio isolates that were resistant, intermediately resistant, or susceptible to the antibiotics tested.

3.4. Cluster Analysis of Vibrio Isolates Based on Inhibition Zone Diameter Data. Cluster analysis was used to determine the relatedness of isolates based on the history of exposure to antibiotics. The inhibition zone diameter data of the twentytwo Vibrio isolates to eleven antibiotics were used to perform the analysis, using Statistica software (version 12). A dendrogram comprising two clusters (1 and 2) was generated (Figure 5). Cluster 1 was further subdivided into two subclusters (1A and 1B). Subclusters of $1 \mathrm{~A}, 1 \mathrm{~B}$, and cluster 2 were analysed for patterns of association of isolates from different sources and locations. As indicated in Figure 4, the largest subcluster (cluster 1B) contained 20 strains from 10 out of the 11 sampling sites. Cluster $1 \mathrm{~A}$ constituted the lone isolate from Pudimoe, while cluster 2 included one of the 2 isolates from boreholes obtained from Lonely Park. None of the five isolates obtained from dam water samples was present in either subcluster $1 \mathrm{~A}$ or cluster 2.

3.5. Biofilm Formation Capacity of Vibrio. All the twenty-two Vibrio isolates were screened in order to determine their potential to form biofilms on polystyrene plates at $37^{\circ} \mathrm{C}$, $35^{\circ} \mathrm{C}$, and $25^{\circ} \mathrm{C}$. Eight (36.4\%) isolates formed biofilms (4 moderate and 4 weak) at $37^{\circ} \mathrm{C}, 14$ (6 strong, 2 moderate, and 
TABLE 3: Distribution patterns of Vibrio species from different sampling types and sites.

\begin{tabular}{|c|c|c|c|c|c|c|}
\hline Sampling site & $\begin{array}{c}\text { Source/ } \\
\text { sample site }\end{array}$ & $\begin{array}{c}\text { Vibrio } \\
\text { vulnificus }\end{array}$ & $\begin{array}{c}\text { Vibrio } \\
\text { parahaemolyticus }\end{array}$ & $\begin{array}{l}\text { Vibrio } \\
\text { mimicus }\end{array}$ & $\begin{array}{l}\text { Vibrio } \\
\text { harveyi }\end{array}$ & $\begin{array}{l}\text { Vibrio } \\
\text { cholerae }\end{array}$ \\
\hline Pudimoe & Borehole (1) & 0 & 0 & 0 & 1 & 0 \\
\hline \multirow{2}{*}{ Choseng } & Borehole (1) & 0 & 0 & 0 & 1 & 0 \\
\hline & Tap (1) & 0 & 0 & 0 & 1 & 0 \\
\hline \multirow{2}{*}{ Lonely } & Borehole (2) & 0 & 2 & 0 & 0 & 0 \\
\hline & Tap (1) & 0 & 1 & 0 & 0 & 0 \\
\hline Seweding & Borehole (1) & 0 & 0 & 1 & 0 & 0 \\
\hline Ramosadi & Borehole (2) & 0 & 2 & 0 & 0 & 0 \\
\hline \multirow{2}{*}{ Ntswanahatshe } & Borehole (4) & 0 & 0 & 0 & 4 & 0 \\
\hline & Tap (1) & 0 & 0 & 0 & 1 & \\
\hline Vryburg & Tap (2) & 0 & 0 & 0 & 2 & 0 \\
\hline Marico Bosveld & $\operatorname{Dam}(1)$ & 1 & 0 & 0 & 0 & 0 \\
\hline \multirow{2}{*}{ Pella } & $\operatorname{Dam}(2)$ & 0 & 0 & 0 & 0 & 2 \\
\hline & Tap (1) & 0 & 0 & 0 & 0 & 1 \\
\hline Coligny & Dam (1) & 0 & 0 & 1 & 0 & 0 \\
\hline Ventersdorp & Tap (1) & 1 & 0 & 0 & 0 & 0 \\
\hline Total & 22 & 2 & 5 & 2 & 10 & 3 \\
\hline
\end{tabular}

6 weak) at $35^{\circ} \mathrm{C}$, and 11 ( 1 strong, 3 moderate, and 7 weak) at $25^{\circ} \mathrm{C}$. Figure 6 is an overview of the biofilm formation potentials of isolates at different temperatures.

\subsection{Characterisation of Vibrio-Specific Bacteriophages}

3.6.1. Transmission Electron Microscopy. Morphological classification of the phages was achieved using previous guidelines [48]. Both phages had icosahedral heads and long contractile tails (Figure 7). Based on these characteristics, the phages were classified as belonging to the family Myoviridae (Ackermann [48]).

3.6.2. Bacteriophage Virulent Assay. Two bacteriophages designated phage $\mathrm{A}$ and phage $\mathrm{B}$, based on their profiles, were used to assess their potentials as biocontrol against all the twenty-two molecularly confirmed environmental Vibrios isolated in the study. Results were interpreted as positive when there was inhibition of bacterial growth or negative when bacterial growth was not inhibited. The outcome of virulence assay revealed phage $\mathrm{A}$ as biologically active against 19 of the 22 Vibrio strains, while phage B was active against 18 isolates. Interestingly, both bacteriophages were active against the same sets of bacterial strains as 17 individual Vibrio strains could be inhibited by both phages $\mathrm{A}$ and $\mathrm{B}$, two by phage A only, and one by phage B only.

3.6.3. Stability of Phage at Different Conditions. The results showed that both phages (vB_VpM_SA3V and
vB_VcM_SA3V) were stable at $\mathrm{pH}$ values, ranging from 4.2 to 10.0. Optimum stability for phage vB_VpM_SA3V was observed at pH 10 (Figure 8), while phage vB_VcM_SA3V displayed optimal stability at neutral $\mathrm{pH}$ (6-7). Both phages could not survive at the acidic $\mathrm{pH}$ of 3.0. The optimum temperature at which both phages were stable was $37^{\circ} \mathrm{C}$, while their growth and survival rates reduced with an increase in temperature. Figures 9-11 show the stability of phages vB_VpM_SA3V and vB_VcM_SA3V to varying $\mathrm{pH}$ and temperatures.

\section{Discussion}

Water is an essential resource for life, and access to safe drinking water is a fundamental human need and a basic right of every individual [50]. Safe drinking water should be void of high concentrations of chemicals and minerals, as well as pathogenic microorganisms. South Africa is located in a semiarid region and receives very less rainfall, resulting in shortage of water, especially potable water. Besides, increased industrialisation and frequent establishment of informal settlements also affect the quality of water, especially in rural areas. Due to scarcity of potable water, most individuals resort to water from other unprotected sources, such as boreholes, rivers, and dams for daily activities. These unprotected sources of water could be contaminated with faecal matter from human and animal origin.

Twenty-two (38.60\%) isolates were identified as Vibrio species through amplification of fragments of omp $W, r f b O 1$, flaE, $\operatorname{sod} B(1), h s p, \operatorname{sod} B$, and $v h h$ genes. The proportion of $V$. 


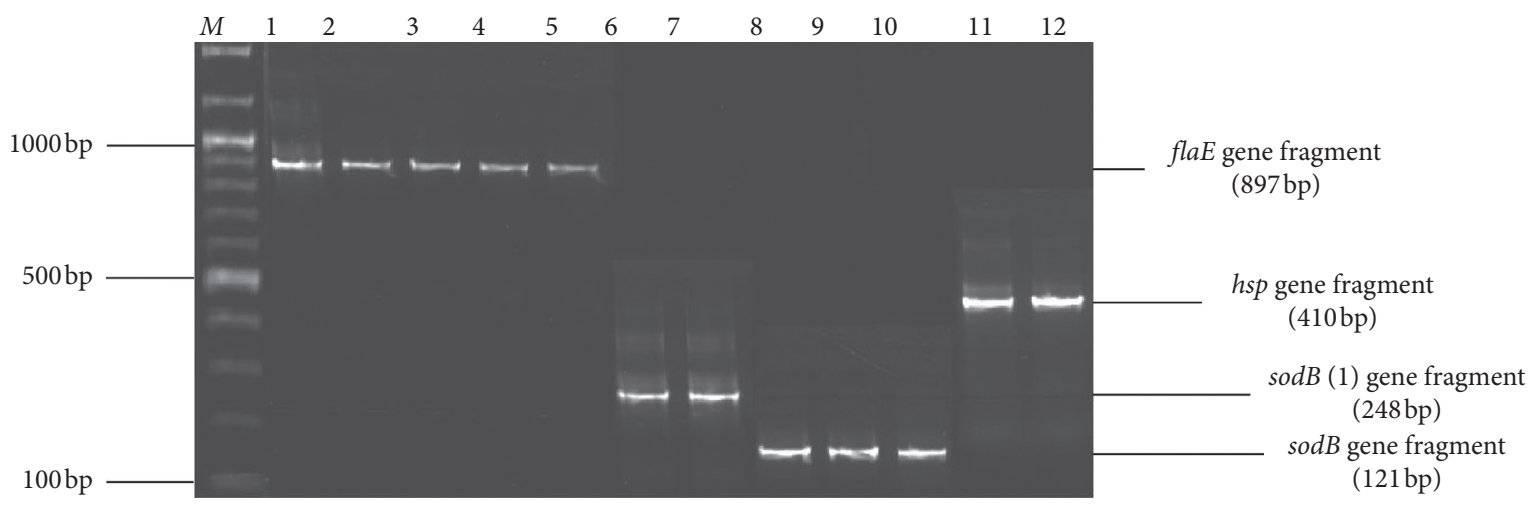

Figure 2: A 2\% (w/v) agarose gel, showing amplicons of fragments of flaE (V. parahaemolyticus), hsp 60 (V. vulnificus), sodB (1) (V. cholerae), and $\operatorname{sodB}$ (V. mimicus) genes amplified during the study. Lane $M=100 \mathrm{bp}$ DNA marker, lanes $1-5=$ fragments of the $f l a E$ gene of positive isolates of $V$. parahaemolyticus, lanes 6-7 = fragments of the $\operatorname{sodB}(1)$ gene amplified from positive isolates of $V$. cholerae, lanes 8-10 = fragments of the $\operatorname{sodB}$ gene of positive isolates of $\mathrm{V}$. mimicus, and lanes 11-12= fragments of the $h s p 60$ gene of positive isolates of V. vulnificus.

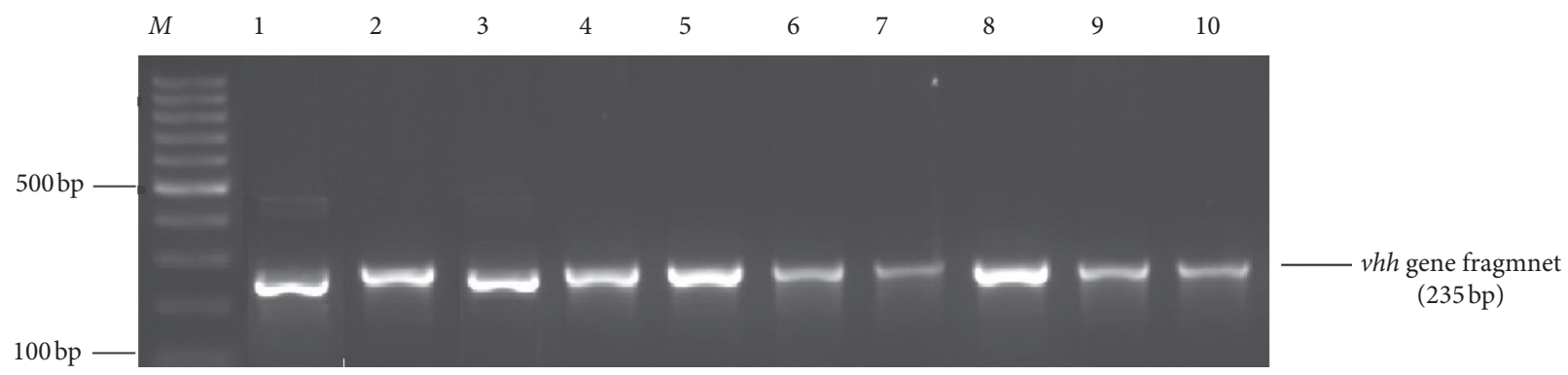

Figure 3: A 2\% (w/v) image of agarose gel showing fragments of the $v$ hh gene amplified from isolates of $V$. harveyi, lane $M=100 \mathrm{bp}$ DNA ladder, and lanes $1-12=$ fragments of the $v$ hh gene.

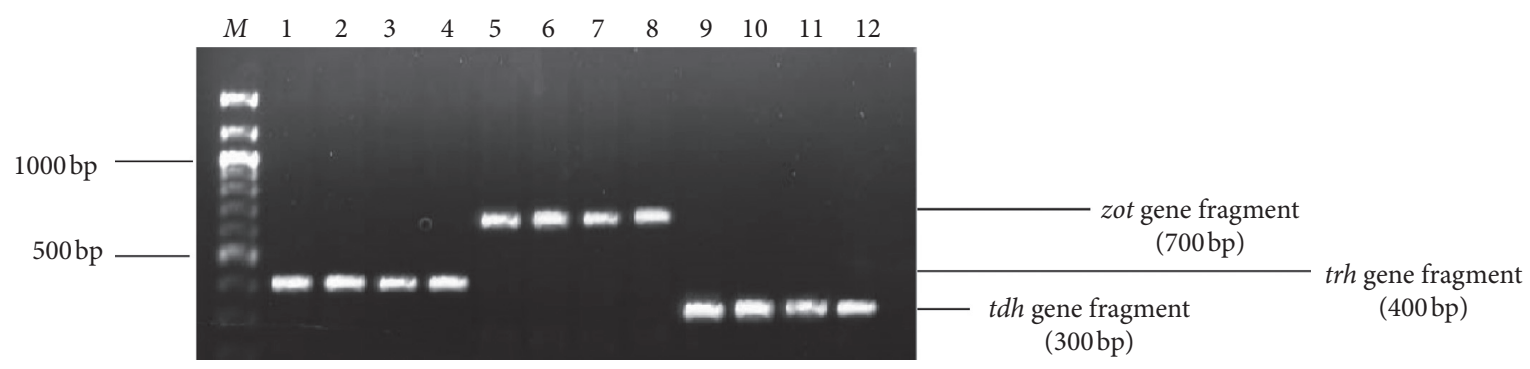

FIGURE 4: Image of agarose gel showing fragments of virulent genes $z o t$, $t r h$, and $t d h$. Lane $M=100 \mathrm{bp}$ DNA marker, lanes $1-4=$ fragments of the $t r h$ gene, lanes $5-8=$ fragments of the $z$ ot gene, and lanes $9-12=$ fragments of the $t d h$ gene.

TABLE 4: Number and percentage of antibiotic resistance of Vibrio isolates recovered from water samples.

\begin{tabular}{|c|c|c|c|}
\hline Antibiotic (disc content) & Resistant (\%) & Intermediate $(\%)$ & Susceptible (\%) \\
\hline Ampicillin $(10 \mu \mathrm{g})$ & $17(77.3)$ & $2(9.1)$ & $3(13.6)$ \\
\hline Cephalothin $(30 \mu \mathrm{g})$ & $21(95.5)$ & $1(4.5)$ & $0(0.0)$ \\
\hline Chloramphenicol $(30 \mu \mathrm{g})$ & $2(9.1)$ & $2(9.1)$ & $18(81.8)$ \\
\hline Ciprofloxacin $(5 \mu \mathrm{g})$ & $1(4.5)$ & $7(31.8)$ & $14(63.6)$ \\
\hline Tetracycline $(30 \mu \mathrm{g})$ & $5(22.7)$ & $1(4.5)$ & $16(72.7)$ \\
\hline Gentamicin $(10 \mu \mathrm{g})$ & $3(13.6)$ & $2(9.1)$ & $17(77.3)$ \\
\hline Kanamycin $(30 \mu \mathrm{g})$ & $3(13.6)$ & $8(36.4)$ & $11(50.0)$ \\
\hline Nalidixic acid $(30 \mu \mathrm{g})$ & $6(27.3)$ & $8(36.4)$ & $8(36.4)$ \\
\hline Trimethoprim-sulfamethoxazole $(1.25 / 23.75 \mu \mathrm{g})$ & $1(4.5)$ & $1(4.5)$ & $20(90.9)$ \\
\hline Streptomycin $(10 \mu \mathrm{g})$ & $9(40.9)$ & $7(31.8)$ & $6(27.3)$ \\
\hline Trimethoprim $(5 \mu \mathrm{g})$ & $3(9.1)$ & $1(4.5)$ & $18(81.8)$ \\
\hline
\end{tabular}




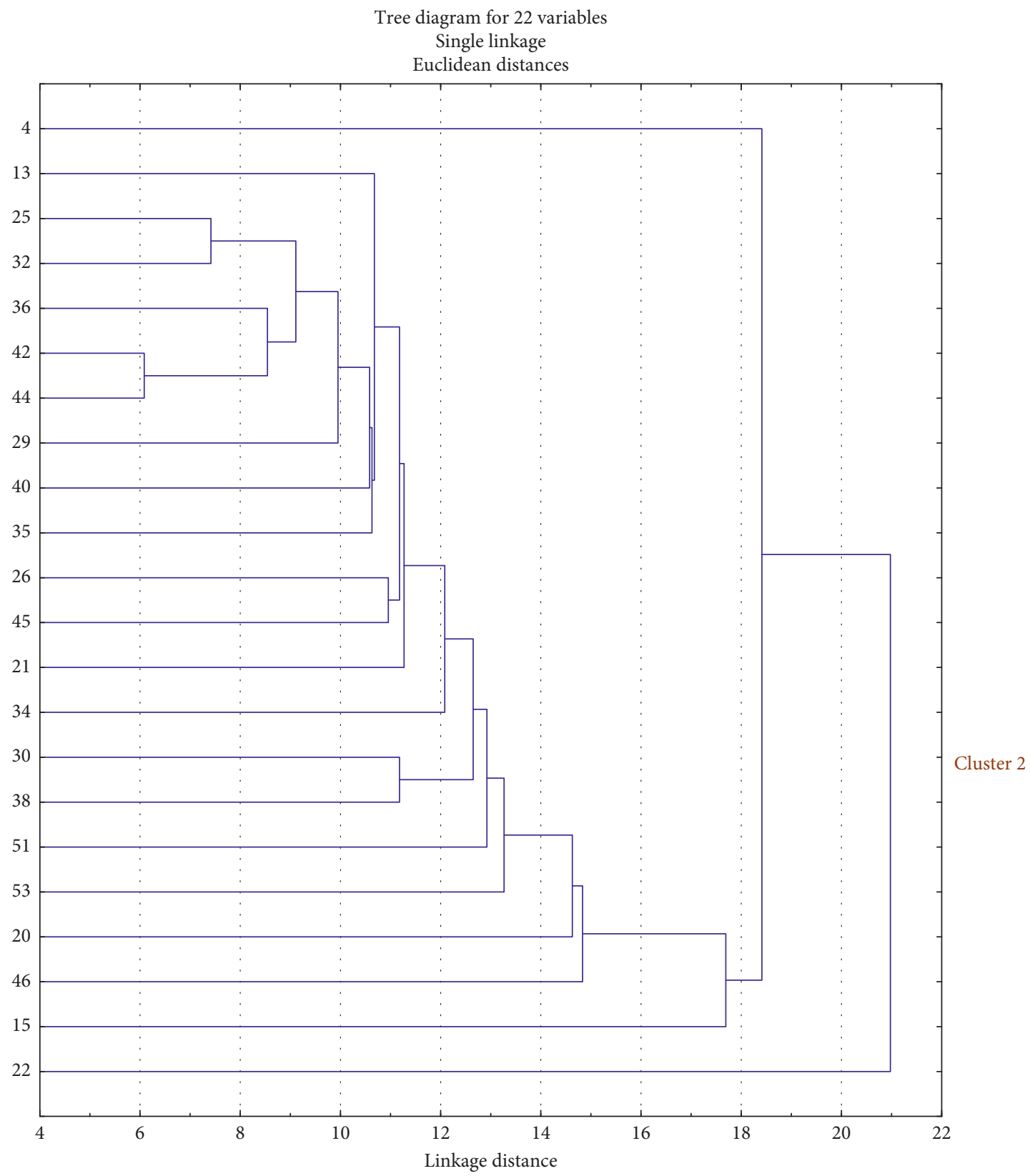

FIGURE 5: Dendrogram showing the relationship between isolates from water samples based on antimicrobial inhibition zone diameter data.

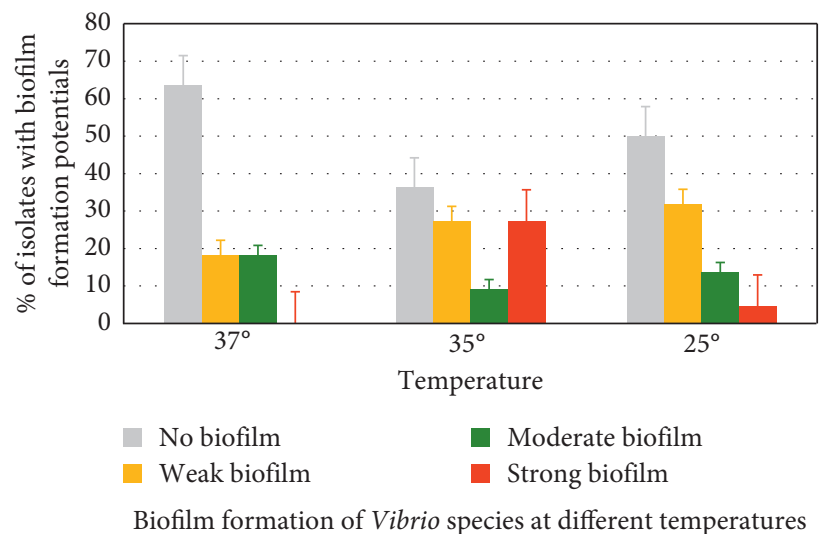

FIgURE 6: Biofilm formation potentials of Vibrio species at different temperatures. 


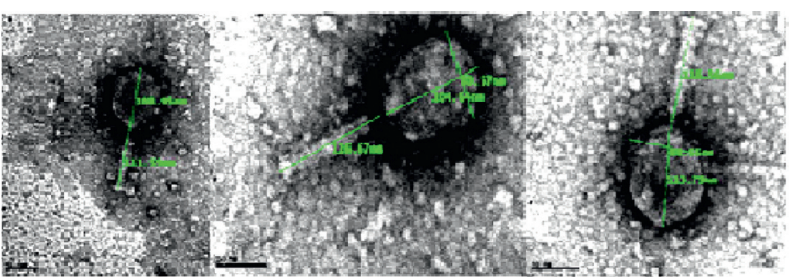

(a)

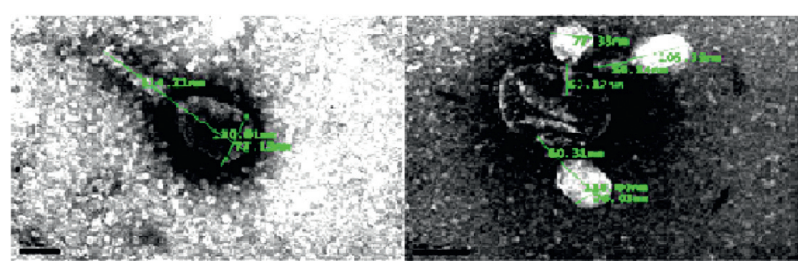

(b)

Figure 7: Transmission electron micrographs of Vibrio-specific bacteriophages isolated from sewage. (a) vB_VpM_SA3V. (b) vB_VcM_SA3V.

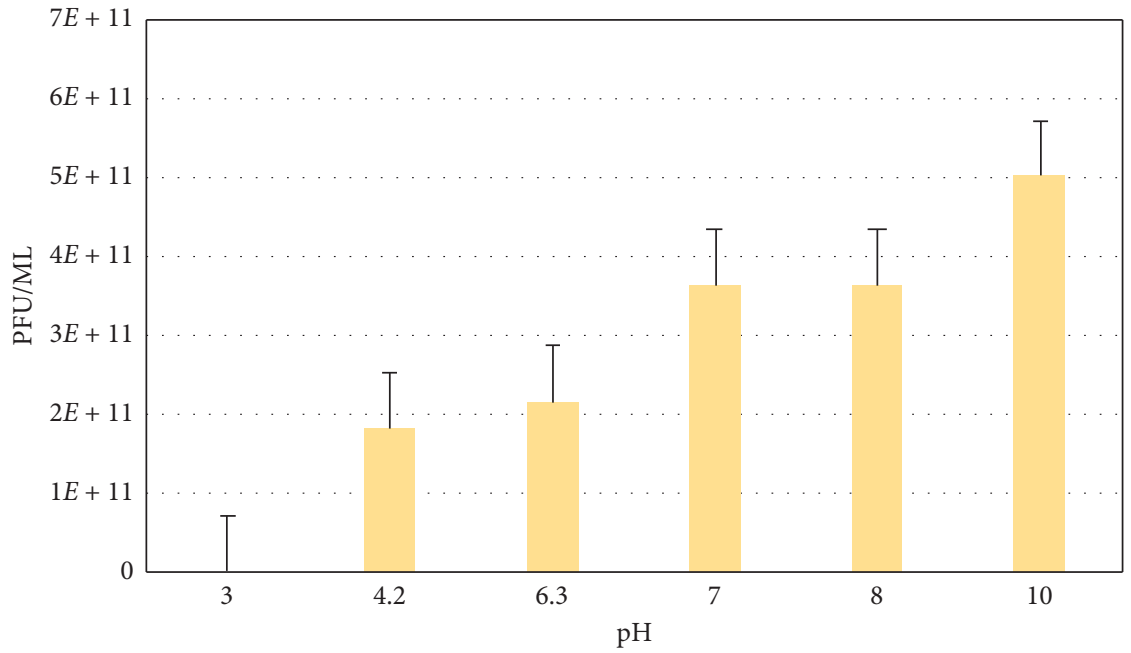

Figure 8: Stability of phage vB_VpM_SA3V at different pH levels.

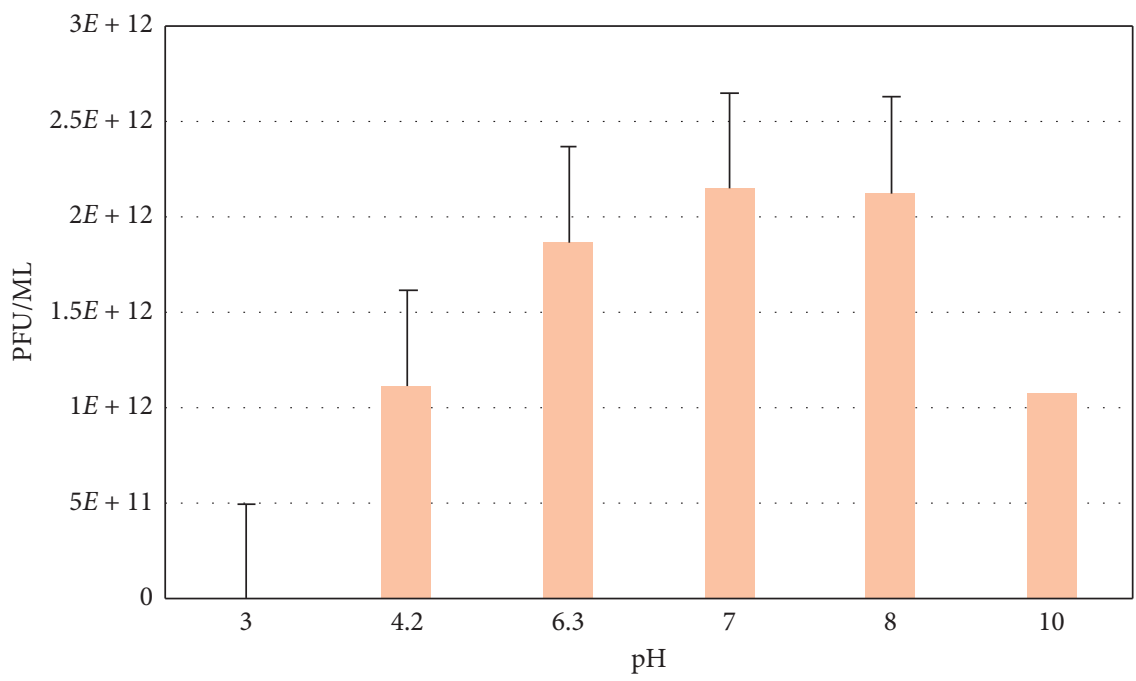

Figure 9: Stability of phage vB_VcM_SA3V at different pH levels.

harveyi was higher $(10(45.45 \%))$ compared to $V$. parahaemolyticus (5 (22.73\%)), V. mimicus (3 (13.64\%)), V. vulnificus $(2(9.09 \%))$, and $V$. cholerae $(2(2.09 \%))$. The negative isolates of these species-specific PCRs could belong to other Vibrio species not included in the study. Similar observations have been reported in previous studies. In these studies, some or most of these Vibrio species were detected in fish and shrimps [51], shrimps only [52], aquatic samples [53], marine fish, and water [54]. The Vibrio species identified comprised thirteen isolates from borehole water, five 


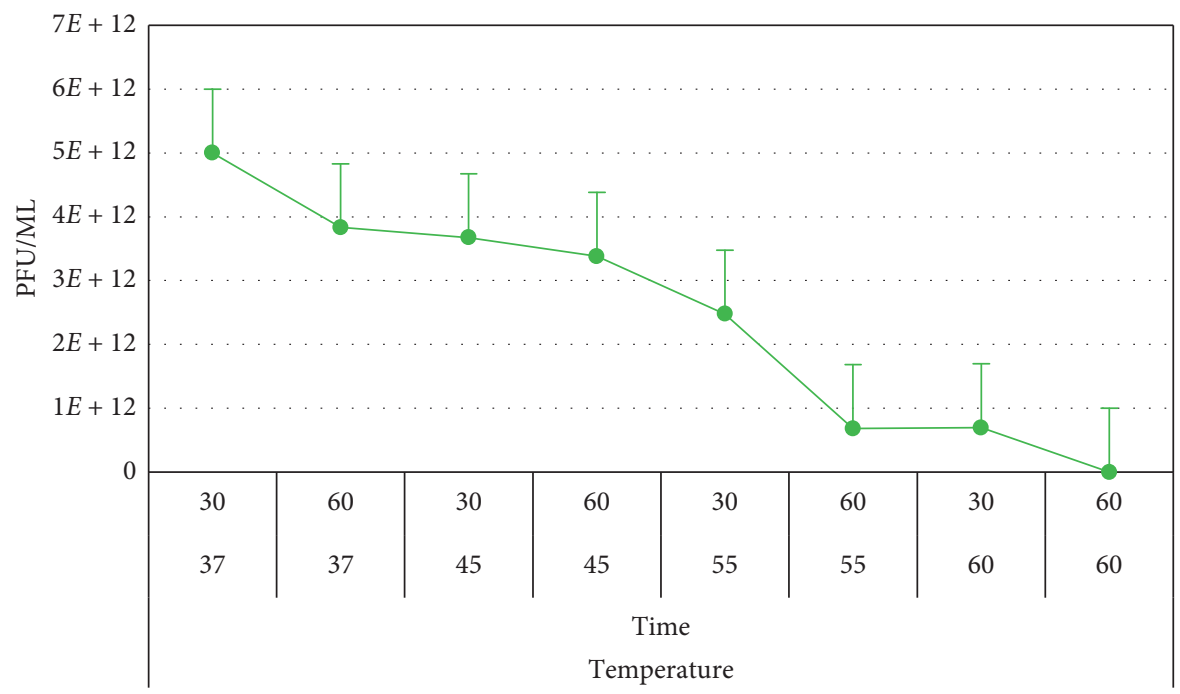

Figure 10: Stability of phage vB_VpM_SA3V at different temperatures.

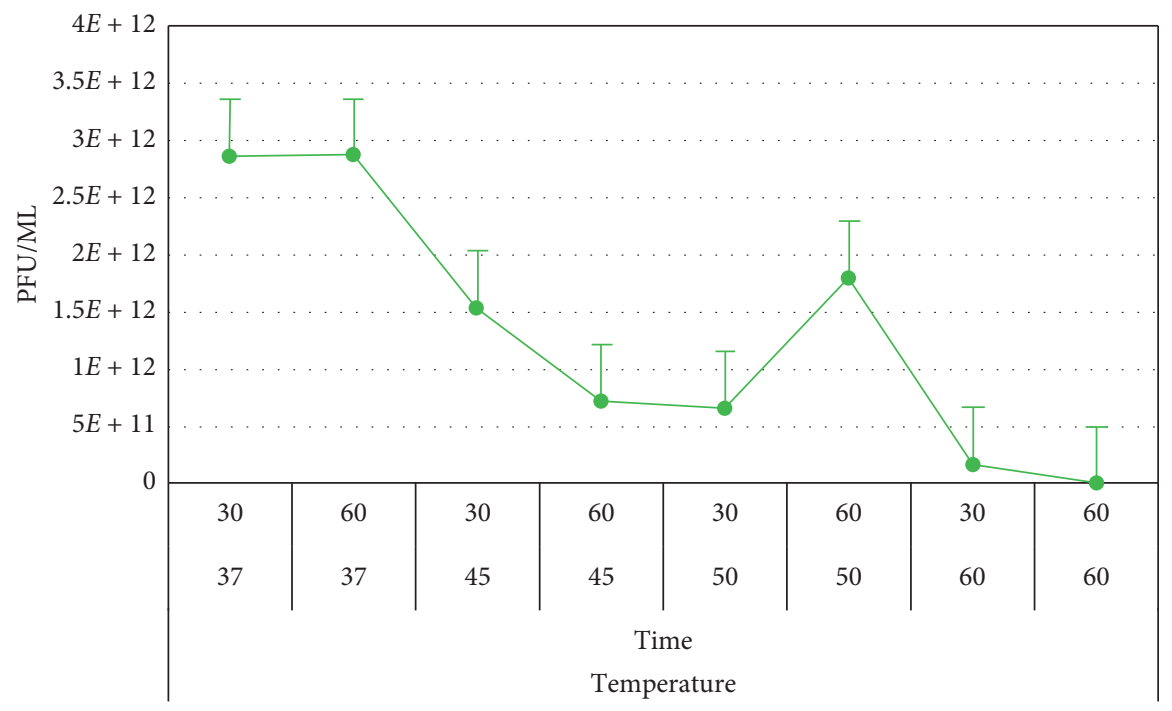

Figure 11: Stability of phage vB_VcM_SA3V at different temperatures.

from tap water, and four from dam water. Vibrio species were dominant in samples from borehole water that do not usually undergo treatment and purification before consumption. Detection of Vibrio species in tap water that undergoes treatment is a cause for concern. These water sources can serve as a potential route for the transmission of Vibrio species to consumers and present significant public health complications when consumed. Thus, their presence in treated tap water highlights the urgent need to improve and adhere to standard operating procedures of wastewater and water purification plants.

The presence of pathogenic microorganisms associated with both self-limiting and life-threatening waterborne infections in water bodies often results from faecal pollution of human and animal origin. This is very common in rural communities and other informal settlements [55]. Poor management of wastewater treatment plants and uncontrolled sewage discharge have been identified as the two major sources of microbial pollution of water sources in South Africa [55]. There is, therefore, a need to monitor both treated water and wastewater for microbial pathogens. An assessment of adherence to standard treatment protocols and the implementation of proper management practices is, therefore, essential to improving the quality of water. Water quality assessment parameters affect optimum performance as well as the quality of the final product. These parameters include the reliability of the plant, nature of raw materials used, management of byproducts, safety, human resources, economic and financial resources, infrastructure, and maintenance [56]. These parameters are very important and should be included in the operational performance assessment tool of each water treatment plant since they directly affect the quality of the finished product. To reduce associated health risks on consumers, the limits for microbial 
contaminants in domestic water should fall within acceptable limits determined by the South African National Standard (SANS) 241 of 2015 [57]. Based on this, no E. coli, total coliform, and heterotrophic bacteria should be present in $100 \mathrm{~mL}$ of drinking water samples. However, Vibrio species is part of heterotrophic bacteria load, an indication that water does not meet the standards of SANS 241 and, therefore, considered unsafe for drinking or household use.

Three of the six virulent genes screened in this study were detected. Four out of 5 (80\%) V. parahaemolyticus isolates, representing $18.2 \%$ of the total Vibrios in the study, harboured $t d h$ and trh virulence genes. This is quite high compared to other studies with lower detection rates $[53,58]$ or the absence of these pathogenicity factors [52]. Nonetheless, detection rates were still lower compared to a study, whereby 31 out of $32(96.8 \%) V$. parahaemolyticus isolates from seafood possessed, at least, one $(n=19)$ or both $(n=13)$ virulent genes [10]. Three Vibrio cholerae isolates and 1 Vibrio mimicus isolate harboured the zot gene (18.18\%). However, these results do not concur with those reported in a previous study [59]. Since the isolates did not harbour any zot virulent genes, contrary to the findings of this study, isolates belonging to the Harveyi clade, comprising $V$. harveyi and $V$. campbellii, possessed both typical and atypical virulent genes $v h h, \operatorname{chi} A, v h p A, \operatorname{ToxR}(\mathrm{Vh})$, and $\operatorname{lu} x \mathrm{R}$ and serine protease. Thus, it is suggested that they might have acquired these virulence determinants from other Vibrio species through horizontal gene transfer [60]. There is need for constant monitoring, even in species that were previously considered to be nonpathogenic.

A large percentage ( $40.91 \%$ to $95.45 \%)$ of Vibrio species obtained in this study were resistant to streptomycin, ampicillin, and cephalothin, however, with higher sensitivity to trimethoprim-sulfamethoxazole, trimethoprim, chloramphenicol, gentamycin, tetracycline, and Ciprofloxacin. However, the percentage of multidrug resistance strains was high $(72.7 \%)$. The proportion of resistant Vibrios to chloramphenicol, gentamicin, and tetracycline was similar to that recorded in Vibrio isolates from aquaculture environments. However, multidrug resistance was higher in our study than reported in these studies [61, 62].

Drug resistance is currently an issue of severe public health concern worldwide, mainly due to the alarming rate of dissemination of resistant determinants in environmental bacterial pathogens. These resistant strains have a negative impact on antibiotic therapy, resulting in difficulties in controlling and managing diseases $[63,64]$. Improper discharge of municipal and industrial wastewater, as well as water from aquaculture systems, has been reported to play significant roles in the dissemination of resistant genes within aquatic ecosystems. It is worthy to note that several clinically used antibiotics are released in an active biological form through faeces and urine to the environment [65-67]. Improperly treated wastewater containing such residues increases the number of antibiotic-resistant bacteria in the environment, which could be transmitted to consumers [68-70]. Cluster analysis of bacterial growth inhibition zone diameter data also revealed very close similarities among isolates from different locations and sources, indicating similar histories of exposure to antibiotics. These findings are similar to a previous report in which cluster analysis of antibiotic-resistant data for Escherichia coli O157 strains revealed a closer relationship between isolates from pig and human faeces compared to cattle and humans [71].

Biofilms are an assemblage of microbial cells enclosed in a polysaccharide matrix irreversibly associated with a surface [72]. In this study, some of the Vibrio strains from water samples displayed the ability to bind to surfaces and form biofilms. Despite the fact that there was variability in the potential to form biofilms at different temperatures, their biofilm-forming ability presents a significant public health concern. This is because biofilms provide cells with enhanced opportunity to resist antimicrobial agents, thus persist in tissues during associated infections [73]. The everincreasing occurrence of multidrug-resistant pathogenic bacteria poses a need for alternative sources of therapy, one of which is the use of bacteriophages [74]. Two bacteriophages (phages A and B) isolated in this study were capable of lysing many antibiotic-resistant Vibrio strains. These phages, therefore, provide alternative strategies for controlling these bacterial contaminants in water, given the fact that most bacterial contaminants exhibit high levels of resistance to conventional water purification chemicals. However, appropriate screening of the phage genomes for the presence of undesirable determinants that can render them unsafe is necessary [75]. The TEM images of both phages revealed they belong to the family Myoviridae based on its conserved and highly characteristic morphology. Bacteriophages belonging to this family are found everywhere in the biosphere; they reside in places such as top soils, plants, animals, or water bodies [76]. However, phages are known to be highly specific at species and strain levels, and determination of their bacterial host range is critical in determining their potential to be utilised as antimicrobial agents. Against this background, it is suggested that the virulence potential of these phages be assessed against other related bacterial species that can occur as microbial contaminants in water.

\section{Conclusion}

The findings of this study revealed the presence of antibiotic-resistant virulent Vibrio species from tap water, boreholes, and dams, making it unsafe for domestic use. Cluster analysis of bacterial growth inhibition zone diameter data revealed very close similarities among isolates from different sources and locations, indicating similar histories of exposure to antibiotics, which is a public health concern. Some of these Vibrios are capable of surviving in a wide range of ecological niches as they can form biofilms at different temperatures. Infection with such strains can persist when associated with humans. However, two phages (A and B) isolated in this study present potential characteristics as reliable and effective biocontrol agents for these strains. The phages belong to the Myoviridae family and are stable over a wide range of $\mathrm{pH}$ and temperatures. However, an assessment of the bacterial host range can greatly improve their chances of 
being used in commercial processes, and appropriate screening of the phage genomes for the presence of undesirable determinants that can render them unsafe is necessary.

\section{Data Availability}

The data used to support the findings of this study are included within the article.

\section{Conflicts of Interest}

The authors declare no conflicts of interest.

\section{Authors' Contributions}

Collins Njie Ateba contributed to conceptualization and funding acquisition; Mpho Defney Maje contributed to formal analysis, investigation, and methodology; Madira Coutlyne Manganyi and Collins Njie Ateba supervised the study; Justine Fri and Christ Donald Kaptchouang Tchatchouang contributed to writing and original draft preparation; and Justine Fri and Collins Njie Ateba contributed to writing, reviewing, and editing.

\section{Acknowledgments}

The authors acknowledge the North-West University for providing the space for bench work and Mr. BJ Morapedi for assisting with the collection of samples. The assistance received from colleagues in the Antibiotic Resistance and Phage Biocontrol Research Group (AREPHABREG) is highly acknowledged. This study was supported, in part, by the National Research Foundation (NRF) and the NorthWest University, South Africa.

\section{Supplementary Materials}

Supplementary Table 1: the number of water samples collected from the different areas during the study. (Supplementary Materials)

\section{References}

[1] Centers for Disease Control and Prevention (CDC), "National enteric disease surveillance: covis annual summary," Summary of Human Vibrio Cases Reported to CDC, Centers for Disease Control and Prevention, Atlanta, GA, 2014.

[2] C. Baker-Austin, J. D. Oliver, M. Alam et al., "Vibrio spp. infections," Nature Reviews Disease Primers, vol. 4, no. 1, 2018.

[3] J. M. Hughes, D. G. Hollis, E. J. Gangarosa, and E. W. Robert, "Non-cholera Vibrio infections in the United States," Annals of Internal Medicine, vol. 88, no. 5, pp. 602-606, 1978.

[4] F. L. Thompson, T. Iida, and J. Swings, "Biodiversity of vibrios," Microbiology and Molecular Biology Reviews, vol. 68, no. 3, pp. 403-431, 2004.

[5] T. Mahapatra, S. Mahapatra, G. R. Babu et al., "Cholera outbreaks in South and southeast Asia: descriptive analysis, 2003-2012," Japanese Journal of Infectious Diseases, vol. 67, no. 3, pp. 145-156, 2014.

[6] G. B. Nair, T. Ramamurthy, S. K. Bhattacharya, B. Dutta, Y. Takeda, and D. A. Sack, "Global dissemination of Vibrio parahaemolyticus serotype O3:K6 and its serovariants," Clinical Microbiology Reviews, vol. 20, no. 1, pp. 39-48, 2007.

[7] A. K. T. Kirschner, S. Schauer, B. Steinberger et al., "Interaction of Vibrio cholerae non-O1/non-O139 with copepods, cladocerans and competing bacteria in the large alkaline lake Neusiedler See, Austria," Microbial Ecology, vol. 61, no. 3, pp. 496-506, 2011.

[8] M. Gennari, V. Ghidini, G. Caburlotto, and M. M. Lleo, "Virulence genes and pathogenicity islands in environmental Vibrio strains nonpathogenic to humans," FEMS Microbiology Ecology, vol. 82, no. 3, pp. 563-573, 2012.

[9] M. K. Waldor and J. J. Mekalanos, "Lysogenic conversion by a filamentous phage encoding cholera toxin," Science, vol. 272, no. 5270, pp. 1910-1914, 1996.

[10] G. Terzi, Ö. Büyüktanır, and N. Yurdusev, "Detection of the tdh and trh genes in Vibrio parahaemolyticus isolates in fish and mussels from middle black sea coast of Turkey," Letters in Applied Microbiology, vol. 49, pp. 757-763, 2010.

[11] H. Hiyoshi, T. Kodama, T. Iida, and T. Honda, "Contribution of Vibrio parahaemolyticus virulence factors to cytotoxicity, enterotoxicity, and lethality in mice," Infection and Immunity, vol. 78, no. 4, pp. 1772-1780, 2010.

[12] G. G. Terzi and J. Martinez-Urtaza, "Molecular characterizations of Vibrio parahaemolyticus in seafood from the black sea, Turkey," Letters in Applied Microbiology, vol. 62, pp. 494-500, 2016.

[13] S. Matsuda, T. Kodama, N. Okada, K. Okayama, T. Honda, and T. Iida, "Association of Vibrio parahaemolyticus thermostable direct haemolysin with lipid rafts is essential for cytotoxicity but not hemolytic activity," Infection and Immunity, vol. 78, no. 2, pp. 603-610, 2010.

[14] R. Chakraborty, S. Sinha, A. K. Mukhopadhyay et al., "Species-specific identification of Vibrio fluvialis by PCR targeted to the conserved transcriptional activation and variable membrane tether regions of the toxR gene," Journal of Medical Microbiology, vol. 55, no. 6, pp. 805-808, 2006.

[15] P. Liang, X. Cui, X. Du, B. Kan, and W. Liang, "The virulence phenotypes and molecular epidemiological characteristics of Vibrio fluvialis in China," Gut Pathogens, vol. 5, no. 1, p. 6, 2013.

[16] T. Saga and K. Yamaguchi, "History of antimicrobial agents and resistant bacteria," Japan Medical Association Journal, vol. 52, pp. 103-108, 2009.

[17] J. Carlet, P. Collignon, D. Goldmann et al., "Society's failure to protect a precious resource: antibiotics," The Lancet, vol. 378, no. 9788, pp. 369-371, 2011.

[18] R. L. Finley, P. Collignon, D. G. J. Larsson et al., "The scourge of antibiotic resistance: the important role of the environment," Clinical Infectious Diseases, vol. 57, no. 5, pp. 704-710, 2013.

[19] T.-F. C. Mah and G. A. O’toole, "Mechanisms of biofilm resistance to antimicrobial agents," Trends in Microbiology, vol. 9, no. 1, pp. 34-39, 2001.

[20] F. H. Yildiz and K. L. Visick, "Vibrio biofilms: so much the same yet so different," Trends in Microbiology, vol. 17, no. 3, pp. 109-118, 2009.

[21] J. Wingender, "Hygienically relevant microorganisms in biofilms of man-made water systems," in Biofilm Highlights, pp. 189-238, Springer, Berlin, Germany, 2011.

[22] J. Wang, Y. D. Niu, J. Chen et al., "Feces of feedlot cattle contain a diversity of bacteriophages that lyse non-O157 Shiga toxin-producing Escherichia coli," Canadian Journal of Microbiology, vol. 61, no. 7, pp. 467-475, 2015.

[23] D. Myelnikov, "An alternative cure: the adoption and survival of bacteriophage therapy in the USSR, 1922-1955," Journal of 
the History of Medicine and Allied Sciences, vol. 73, no. 4, pp. 385-411, 2018.

[24] J. Gu, X. Liu, Y. Li et al., "A method for generation phage cocktail with great therapeutic potential," PLoS One, vol. 7, no. 3, Article ID e31698, 2012.

[25] M. D. Safwat, A. E. Farouk, M. A. Mohamed, R. M. Abd ElBaky, and J. John, "Isolation and evaluation of cocktail phages for the control of multidrug-resistant Escherichia coli serotype O104:H4 and E. coli O157:H7 isolates causing diarrhoea," FEMS Microbiology Letters, vol. 365, 2017.

[26] C. Osunla and A. Okoh, "Vibrio pathogens: a public health concern in rural water resources in sub-saharan Africa," International Journal of Environmental Research and Public Health, vol. 14, no. 10, p. 1188, 2017.

[27] J. P. S. Cabral, "Water microbiology. Bacterial pathogens and water," International Journal of Environmental Research and Public Health, vol. 7, pp. 3657-3703, 2010.

[28] J. M. Brunkard, E. Ailes, V. A. Roberts et al., "Surveillance for waterborne disease outbreaks associated with drinking water-United States, 2007-2008," MMWR. Morbidity and Mortality Weekly Report, vol. 60, pp. 38-68, 2011.

[29] Oxfam International, "Oxfam and Islamic Relief warn of crisis in Yemen as families survive on diet of tea and bread," in Human Rights Documents, Brill, Leiden, Netherlands, 2011.

[30] C. N. Ateba and M. D. Maribeng, "Detection of Enterococcus species in groundwater from some rural communities in the Mmabatho area, South Africa: a risk analysis," African Journal of Microbiology Research, vol. 5, pp. 3930-3935, 2011.

[31] P. T. Phokela, C. N. Ateba, and D. T. Kawadza, "Assessing antibiotic resistance profiles in Escherichia coli and Salmonella species from groundwater in the Mafikeng area, South Africa," African Journal of Microbiology Research, vol. 5, pp. 5902-5909, 2011.

[32] C. N. Ateba and M. Mbewe, "Detection of Escherichia coli O157: H7 virulence genes in isolates from beef, pork, water, human and animal species in the northwest province, South Africa: public health implications," Research in Microbiology, vol. 162, no. 3, pp. 240-248, 2011.

[33] C. N. Ateba, K. P. Lekoma, and D. T. Kawadza, "Detection of $v a n A$ and $v a n B$ genes in vancomycin-resistant enterococci (VRE) from groundwater using multiplex PCR analysis," Journal of Water and Health, vol. 11, no. 4, pp. 684-691, 2013.

[34] S. G. Mulamattathil, C. Bezuidenhout, M. Mbewe, and C. N. Ateba, "Biofilm formation in surface and drinking water distribution systems in Mafikeng, South Africa," South African Journal of Science, vol. 110, no. 11/12, pp. 1-9, 2014.

[35] American Public Health Association, American Water Works Association, Water Pollution Control Federation, Water Environment Federation Standard Methods for the Examination of Water and Wastewater, American Public Health Association, Washington, DC, USA, 1915.

[36] J. J. Doyle and J. L. Doyle, "DNA and higher plant systematics: some examples from the legumes," Molecular Techniques in Taxonomy, Springer, Berlin, Germany, pp. 101-115, 1991.

[37] E. Stackebrand and M. Goodfellow, Nucleic Acid Techniques in Bacterial Systematics, Wiley, Hoboken, NJ, USA, 1991.

[38] A. K. Goel, S. Ponmariappan, D. V. Kamboj, and L. Singh, "Single multiplex polymerase chain reaction for environmental surveillance of toxigenic-pathogenic $\mathrm{O} 1$ and non-O1 Vibrio cholerae," Folia Microbiologica, vol. 52, no. 1, pp. 81-85, 2007.

[39] C. L. Tarr, J. S. Patel, N. D. Puhr, E. G. Sowers, C. A. Bopp, and N. A. Strockbine, "Identification of Vibrio isolates by a multiplex PCR assay and rpoB sequence determination,"
Journal of Clinical Microbiology, vol. 45, no. 1, pp. 134-140, 2007.

[40] B. Maiti, M. Shekar, R. Khushiramani, I. Karunasagar, and I. Karunasagar, "Evaluation of RAPD-PCR and protein profile analysis to differentiate Vibrio harveyi strains prevalent along the southwest coast of India," Journal of Genetics, vol. 88, no. 3, pp. 273-279, 2009.

[41] F. G. R. D. Menezes, S. D. S. Neves, O. V. D. Sousa et al., "Detection of virulence genes in environmental strains of Vibrio cholerae from estuaries in northeastern Brazil," Revista do Instituto de Medicina Tropical de São Paulo, vol. 56, no. 5, pp. 427-432, 2014.

[42] A. W. Bauer, W. M. M. Kirby, J. C. Sherris, and M. Turck, "Antibiotic susceptibility testing by a standardized single disk method," American Journal of Clinical Pathology, vol. 45, no. 4_ts, pp. 493-496, 1966.

[43] Clinical and Laboratory Standards Institute (CLSI), Performance Standards for Antimicrobial Susceptibility Testing, Clinical and Laboratory Standards Institute (CLSI), Wayne, PA, USA, 2014.

[44] G. A. O’Toole, L. A. Pratt, P. I. Watnick, D. K. Newman, V. B. Weaver, and R. Kolter, "Genetic approaches to study of biofilms," in Methods in Enzymology, vol. 310, pp. 91-109, Academic Press, Cambridge, MA, USA, 1999.

[45] M. H. Adams, Bacteriophages, Interscience Publishers, Hoboken, NJ, USA, 1959.

[46] Y. D. Niu, R. P. Johnson, Y. Xu et al., "Host range and lytic capability of four bacteriophages against bovine and clinical human isolates of Shiga toxin-producing Escherichia coli O157: H7," Journal of Applied Microbiology, vol. 107, no. 2, pp. 646-656, 2009.

[47] J. Sambrook and D. W. Russell, Molecular Cloning: A Laboratory Manual, Cold Spring Harbor Laboratory Press, New York, NY, USA, 3rd edition, 2001.

[48] H.-W. Ackermann, "5500 Phages examined in the electron microscope," Archives of Virology, vol. 152, no. 2, pp. 227-243, 2007.

[49] A. M. Kropinski, D. Prangishvili, and R. Lavigne, "Position paper: the creation of a rational scheme for the nomenclature of viruses of Bacteria and Archaea," Environmental Microbiology, vol. 11, pp. 2775-2777, 2009.

[50] World Health Organisation (WHO), Nitrite in DrinkingWater. Background Document for Preparation of WHO Guidelines for Drinking Water Quality, World Health Organization, Geneva, Switzerland, 2011.

[51] M. Raissy, E. Rahimi, R. Azargun, M. Moumeni, and H. R. Sohrabi, "Molecular detection of Vibrio spp. in fish and shrimp from the Persian gulf," Journal of Food Biosciences and Technology, vol. 5, pp. 49-52, 2015.

[52] M. R. Kriem, B. Banni, H. El Bouchtaoui et al., "Prevalence of Vibrio spp. in raw shrimps (Parapenaeus longirostris) and performance of a chromogenic medium for the isolation of Vibrio strains," Letters in Applied Microbiology, vol. 61, no. 3, pp. 224-230, 2015.

[53] A. Economopoulou, D. Chochlakis, M. A. Almpan et al., "Environmental investigation for the presence of Vibrio species following a case of severe gastroenteritis in a touristic island," Environmental Science and Pollution Research, vol. 24, no. 5, pp. 4835-4840, 2017.

[54] J. Fri, R. Ndip, H. Njom, and A. Clarke, "Occurrence of virulence genes associated with human pathogenic vibrios isolated from two commercial dusky kob (Argyrosmus japonicus) farms and Kareiga estuary in the Eastern Cape Province, South 
Africa," International Journal of Environmental Research and Public Health, vol. 14, no. 10, p. 1111, 2017.

[55] G. Z. Teklehaimanot, B. Genthe, I. Kamika, and M. N. B. Momba, "Prevalence of enteropathogenic bacteria in treated effluents and receiving water bodies and their potential health risks," Science of the Total Environment, vol. 518-519, pp. 441-449, 2015.

[56] S. Quadros, M. João Rosa, H. Alegre, and C. Silva, “A performance indicators system for urban wastewater treatment plants," Water Science and Technology, vol. 62, no. 10, pp. 2398-2407, 2010.

[57] SANS South African National, Standard 241-1: Drinking Water. Part 1: Microbiological, Physical, Aesthetic and Chemical Determinants, SANS South African National, Bethesda, MD, USA, 2015.

[58] J. C. Mahoney, M. J. Gerding, S. H. Jones, and C. A. Whistler, "Comparison of the pathogenic potentials of environmental and clinical Vibrio parahaemolyticus strains indicates a role for temperature regulation in virulence," Applied and Environmental Microbiology, vol. 76, no. 22, pp. 7459-7465, 2010.

[59] S. Khouadja, E. Suffredini, B. Baccouche, L. Croci, and A. Bakhrouf, "Occurrence of virulence genes among Vibrio cholerae and Vibrio parahaemolyticus strains from treated wastewaters," Environmental Monitoring and Assessment, vol. 186, no. 10, pp. 6935-6945, 2014

[60] H. A. D. Ruwandeepika, T. Defoirdt, P. P. Bhowmick, M. Shekar, P. Bossier, and I. Karunasagar, "Presence of typical and atypical virulence genes in Vibrio isolates belonging to the Harveyi clade," Journal of Applied Microbiology, vol. 109, no. 3, pp. 888-899, 2010.

[61] E. O. Igbinosa, "Detection and antimicrobial resistance of Vibrio isolates in aquaculture environments: implications for public health," Microbial Drug Resistance, vol. 22, no. 3, pp. 238-245, 2016.

[62] J. Fri, R. N. Ndip, H. A. Njom, and A. M. Clarke, "Antibiotic susceptibility of non-cholera vibrios isolated from farmed and wild marine fish (Argyrosomus japonicus), Implications for Public Health," Microbial Drug Resistance, vol. 24, no. 9, pp. 1296-1304, 2018

[63] T. G. Slama, A. Amin, S. A. Brunton et al., "A clinician's guide to the appropriate and accurate use of antibiotics: the Council for Appropriate and Rational Antibiotic Therapy (CARAT) criteria," The American Journal of Medicine, vol. 118, no. 7, pp. 1-6, 2005.

[64] M. Ansari and M. Raissy, "In-vitro susceptibility of commonly used antibiotics against Vibrio spp. isolated from Lobster (Panulirus homarus)," African Journal of. Microbiology Research, vol. 4, pp. 2629-2631, 2011.

[65] A. C. Singer, V. Colizza, H. Schmitt et al., "Assessing the ecotoxicologic hazards of a pandemic influenza medical response," Environmental Health Perspectives, vol. 119, no. 8, pp. 1084-1090, 2011.

[66] Q.-Q. Zhang, G.-G. Ying, C.-G. Pan, Y.-S. Liu, and J.-L. Zhao, "Comprehensive evaluation of antibiotics emission and fate in the river basins of China: source analysis, multimedia modeling, and linkage to bacterial resistance," Environmental Science \& Technology, vol. 49, no. 11, pp. 6772-6782, 2015.

[67] P. Verlicchi and E. Zambello, "Predicted and measured concentrations of pharmaceuticals in hospital effluents. Examination of the strengths and weaknesses of the two approaches through the analysis of a case study," Science of the Total Environment, vol. 565, pp. 82-94, 2016.
[68] B. Li and T. Zhang, "Biodegradation and adsorption of antibiotics in the activated sludge process," Environmental Science \& Technology, vol. 44, no. 9, pp. 3468-3473, 2010.

[69] Y. Luo, W. Guo, H. H. Ngo et al., "A review on the occurrence of micropollutants in the aquatic environment and their fate and removal during wastewater treatment," Science of the Total Environment, vol. 473-474, pp. 619-641, 2014.

[70] C.-E. Chen, H. Zhang, G.-G. Ying, L.-J. Zhou, and K. C. Jones, "Passive sampling: a cost-effective method for understanding antibiotic fate, behaviour and impact," Environment International, vol. 85, pp. 284-291, 2015.

[71] C. R. Kokare, S. Chakraborty, A. N. Khopade, and K. R. Mahadik Biofilm, "Importance and applications," Indian Journal of Biotechnology, vol. 8, pp. 159-168, 2009.

[72] C. N. Ateba and C. C. Bezuidenhout, "Characterisation of Escherichia coli $\mathrm{O} 157$ strains from humans, cattle and pigs in the North-West Province, South Africa," International Journal of Food Microbiology, vol. 128, no. 2, pp. 181-188, 2008.

[73] L. Hall-Stoodley, J. W. Costerton, and P. Stoodley, "Bacterial biofilms: from the natural environment to infectious diseases," Nature Reviews Microbiology, vol. 2, no. 2, pp. 95-108, 2004.

[74] S. Schwarz, A. Loeffler, and K. Kadlec, "Bacterial resistance to antimicrobial agents and its impact on veterinary and human medicine," Veterinary Dermatology, vol. 28, no. 1, pp. 82-e19, 2017.

[75] H. Wei, "Bacteriophages, revitalized after 100 years in the shadow of antibiotics," Virologica Sinica, vol. 30, no. 1, pp. 1-2, 2015.

[76] A. Lopes, P. Tavares, M.-A. Petit, R. Guérois, and S. ZinnJustin, "Automated classification of tailed bacteriophages according to their neck organization," BMC Genomics, vol. 15, no. 1, p. 1027, 2014. 